\title{
Infection by Toxoplasma gondii in Neotropical non-human primates ${ }^{1}$
}

\author{
Juliana S. Pires ${ }^{2}$, Carlos T. Ribeiro ${ }^{3}$, Paulo Roberto de Carvalho Filho ${ }^{4}$, Alcides Pissinatti ${ }^{5}$, \\ Walter Flausino ${ }^{6}$ and Carlos Wilson G. Lopes ${ }^{6 *}$
}

\begin{abstract}
Pires J.S., Ribeiro C.T., Carvalho Filho P.R., Pissinatti A., Flausino W. \& Lopes C.W.G. 2012. Infection by Toxoplasma gondii in Neotropical non-human primates. Pesquisa Veterinária Brasileira 32(10):1041-1044. Departamento de Parasitologia Animal, Instituto de Veterinária, Universidade Federal Rural do Rio de Janeiro, BR 465 Km 7, Seropédica, RJ 23890-000, Brazil. E-mail: lopescwg@ufrrj.br

Toxoplasma gondii (Nicolle et Manceaux, 1909) is an obligatory intracellular protozoan parasite of warm animals, including human and non-human primates. Domestic and wild felids are considered definitive hosts. Several authors have already identified lesions in New World primates caused by T. gondii. Nevertheless, little is known about serological studies on those animals. With this reason, New World non-human primates of the genera Cebus and Callithrix that were apprehended by governmental authorities and sent to the Wildlife Screening Center (Cetas)/IBAMA, at the municipality of Seropédica, state of Rio Janeiro, were bled and sera were submitted to the indirect hemagglutination test for detection of anti-T. gondii antibodies. From 21 sera of Cebus primates, 76.19\% (16/21) had anti- $T$. gondii antibodies. Titles varied from 16 to 2048. In samples from 21 Callithrix, only $4.5 \%(1 / 22)$ had anti-T. gondii antibodies. Only one animal had a title of 32 . During all the time those animals were clinical evaluated until sample was collected; none of them had any clinical sign or sequel related to infection by $T$. gondii. The fact that the origin of these primates is unknown and that there is no information about their feeding habits before captivity makes it difficult to determine the source of $T$. gondii infection.
\end{abstract}

INDEX TERMS: Toxoplasma gondii, Neotropical primates, indirect hemagglutination test.

RESUMO.- [Infecção por Toxoplasma gondii em primatas neotropicais não-humanos.] Toxoplasma gondii (Nicolle et Manceaux, 1909) é um protozoário parasita intracelular obrigatório de animais homeotérmicos, incluindo primatas humanos e não humanos, e que tem felídeos domésticos e silvestres como hospedeiros definitivos. Inúmeros trabalhos já identificaram lesões causadas por T. gon-

\footnotetext{
${ }^{1}$ Received on August 4, 2011.

Accepted for publication on May 30, 2012.

${ }^{2}$ Faculdade de Medicina Veterinária, Centro Universitário Serra dos Órgãos (Unifeso), Av. Alberto Torres 111, Alto, Teresópolis, RJ 25964-004, Brazil.

${ }^{3}$ Curso de Pós-Graduação em Ciências Veterinárias, Universidade Federal Rural do Rio de Janeiro (UFRRJ), Seropédica, RJ 23890-000, Brazil.

${ }^{4}$ Serviço de Vigilância Agropecuária do Porto de Santos, Ministério da Agricultura, Pecuária e Abastecimento, Rua XV de novembro, 122 - Centro, Santos, Brazil. E-mail: paulo.carvalho@agricultura.gov.br

${ }^{5}$ Centro de Primatologia do Rio de Janeiro, Guapimirim, RJ, Brazil. E-mail: pissinatticprj@terra.com.br

${ }^{6}$ Departamento de Parasitologia Animal, Instituto de Veterinária, UFRRJ, Seropédica, RJ. CNPq fellowship. *Corresponding author: lopescwg@ufrrj.br
}

dii em primatas neotropicais, entretanto, poucos estudos abordando a resposta sorológica destes animais ao parasito foram feitos. Com este intuito, primatas neotropicais do gênero Cebus e Callithrix apreendidos por órgãos governamentais e enviados ao Centro de Triagem de Animais Silvestres (Cetas)/IBAMA, no município de Seropédica/RJ, tiveram amostras de sangue coletadas e as alíquotas séricas submetidas ao teste de hemaglutinação indireta para detecção de anticorpos anti-T. gondii. Dos 21 animais do gênero Cebus avaliados, em 76,19\% (16/21) das amostras foram identificados anticorpos hemaglutinantes anti-T. gondii. Os títulos hemaglutinantes variaram desde 16 até 2048. Por outro lado, dos 22 primatas do gênero Callithrix cujas amostras séricas foram testadas, apenas 4,5\% (1/22) apresentaram anticorpos anti-T. gondii. Apenas o título de 32 foi identificado em um único animal. Durante a avaliação clínica e o tempo em que os animais permaneceram no CETAS, desde a chegada, em nenhum animal foram observados sinais clínicos ou sequelas condizentes com a infecção por $T$. gondii. 0 desconhecimento sobre a verdadeira procedência desses símios, bem como os aspectos sanitários relativos à 
alimentação deles dificulta a determinação da fonte de infecção por T. gondii.

TERMOS DE INDEXAÇÃO: Toxoplasma gondii, primatas neotropicais, hemaglutinação indireta.

\section{INTRODUCTION}

The relationship between Toxoplasma gondii and non-human primates is well discussed. African and Eurasian monkeys tend to be more resistant to toxoplasmosis, while some species from the New World are extremely susceptible to the disease, leading some of them to be involved in a sudden outbreak or death in colonies around the world (Innes 1997).

In general, it is considered that New World primates are more susceptible to toxoplasmosis than those of the Old World (Remington et al. 1965, Anderson \& McClure 1982, Cunningham et al. 1992, Innes 1997, Epiphanio et al. 2001), based on frequencies of case reports and on experimental studies (Anderson \& McClure 1982).

Ekanayake et al. (2004) described the first report of antibodies anti-T. gondii in Macaca sinica which is endemic in Sri Lanka, using modifying agglutination test (MAT). In this article, it was observed that primates, which get in contact with human dwellings, had higher prevalence $119 \%$ infected, $\mathrm{p}<0.0001$ ) than those that were restricted to forestry habitat, in which anti-T. gondii antibodies had not been observed.

In India, a study was developed by using the indirect hemagglutination test (IHT) to determine the prevalence of anti-T. gondii antibodies in sera of rhesus monkeys, where was found that from 94 monkeys, 56.4\% of them showed titles higher or equal to eight. Hemagglutinant titles higher than eight were observed in $28.7 \%$, whereas $17 \%$ of the animals had titles around 128 or above (Chhabra et al. 1976).

According to Garcia et al. (2005), with respect to seroprevalence of anti-T. gondii antibodies for MAT in free living Cebus (Capuchin) and Alouatta caraya (Black Howler Monkey) in the Paraná river basin, Brazil, there is a significant difference between prevalence in both cited species, and $30.2 \%$ of captured Cebus spp. were positive, but only $17.6 \%$ of $A$. caraya were positive. In sixteen animals, one $(6.25 \%)$ Cebus had agglutinant anti-T. gondii antibodies with titers over 32 and $93.75 \%(15 / 16)$ with positive reactions until the $1 / 16$ dilution. They explain that this difference can be due to the fact that Cebus spp. are more terrestrial than A. caraya and may be able to get infected by oocysts in feces of wild felids, as the jaguarondi (Herpailurus yagouaroundi) very common in the region.

Prevalence of toxoplasmosis was studied in 47 primates from the zoological garden at Santa Fé in Medellãn, Colômbia. Specific titles of IgG (1/64) were detected in $40.9 \%$ of C. albifrons, $13.3 \%$ of $C$. capucinus. But in C. apella not any anti-T. gondii reaction was observed; all of the monkeys were negative for anti-T. gondii IgM antibodies (Cadavid et al. 1991).

Therefore, objective of this investigation is to evaluate the frequency of infection of T. gondii through identification of hemagglutinant antibodies in Neotropical non-human primates apprehended by governmental authorities and sent to Wildlife Screening Center (Cetas/IBAMA) at municipality of Seropédica/RJ, Brazil.

\section{MATERIALS AND METHODS}

In this study, blood samples were taken from 43 non-human primates, 22 Callithrix and 21 Cebus. Marmoset e Capuchin monkeys apprehended by governmental authorities and sent to the Wildlife Screening Center (Cetas) of the Brazilian Institute of Environment and Renewed Natural Resources (IBAMA), Seropédica, State of Rio de Janeiro, Brazil, where they remain until to be sent to commercial, conservationist or scientific breeders credited by IBAMA or other institutions for maintenance of animals of the national fauna.

Serology of samples were carried out at Laboratório de Coccídios e Coccidioses, Departamento de Parasitologia Animal, Instituto de Veterinária, Projeto Sanidade Animal Embrapa/UFRRJ. The indirect hemaglutination test (commercial Kit-HAI TOXO®, Wama Produtos para Laboratório Ltda, São Carlos, SP) was used for detection of hemagglutinant antibodies against $T$. gondii. The dilution of serum samples started at 1:16, executed in two-fold sequential dilutions, until 1:2048. Serum reactions equal or higher than 1:16 were considered positive samples.

Forty three New World monkeys' serum samples consisted of 15 females and six males of Cebus, six C. apella, one C. nigritus, one $C$. xanthosternos, one $C$. albifrons and 12 hybrids (Table 1 ). Table 2 corresponded to 22 Callithrix primates and consisted of serum samples from 15 females and 7 males. Ages were 14 adults, 4 young and 4 younglings. Two animals were $C$. jacchus and 20 were hybrids among species of the genus Callithrix.

Feeding of these animals in captivity is a very important factor for T. gondii transmission, since transmission of cysts is associated to ingestion of raw meat or partially cooked. While the animals stayed at Cetas, they were fed on fruits, vegetables and animal protein, consisting of commercial food or cooked meat. The water used was considered drinkable as provided from the public distribution company.

Table 1. Neotropical primates of genus Cebus under captivity at Cetas/IBAMA, RJ

\begin{tabular}{|c|c|c|c|c|}
\hline № & Collect data & Cage & Species & Sex \\
\hline 1 & July $18^{\text {th }} 2005$ & Q08 & C. nigrittus & $\mathrm{F}$ \\
\hline 2 & July $18^{\text {th }} 2005$ & Q08 & C. apella & $\mathrm{F}$ \\
\hline 3 & July $18^{\text {th }} 2005$ & Q08 & C. apella & $\mathrm{F}$ \\
\hline 4 & July $18^{\text {th }} 2005$ & Q08 & C. apella & $\mathrm{M}$ \\
\hline 5 & July $18^{\text {th }} 2005$ & Q10 & C. xanthosternos & $\mathrm{F}$ \\
\hline 6 & July $18^{\text {th }} 2005$ & Q10 & Hybrid & $\mathrm{F}$ \\
\hline 7 & July $18^{\text {th }} 2005$ & Q10 & Hybrid & M \\
\hline 8 & July $18^{\text {th }} 2005$ & Q10 & Hybrid & $\mathrm{F}$ \\
\hline 9 & July $18^{\text {th }} 2005$ & Q11 & Hybrid & $\mathrm{F}$ \\
\hline 10 & July $18^{\text {th }} 2005$ & Q11 & Hybrid & $\mathrm{F}$ \\
\hline 11 & July $18^{\text {th }} 2005$ & Q11 & Hybrid & M \\
\hline 12 & July $18^{\text {th }} 2005$ & Q11 & Hybrid & $\mathrm{F}$ \\
\hline 13 & July $18^{\text {th }} 2005$ & Q11 & C. albifrons & $\mathrm{F}$ \\
\hline 14 & July $18^{\text {th }} 2005$ & Q12 & C. apella & M \\
\hline 15 & July $18^{\text {th }} 2005$ & Q12 & C. apella & $\mathrm{F}$ \\
\hline 16 & July $18^{\text {th }} 2005$ & Q12 & C. apella & $\mathrm{F}$ \\
\hline 17 & July $18^{\text {th }} 2005$ & Q04 & Hybrid & $\mathrm{F}$ \\
\hline 18 & July $18^{\text {th }} 2005$ & Q04 & Hybrid & M \\
\hline 19 & July $18^{\text {th }} 2005$ & Q04 & Hybrid & $\mathrm{F}$ \\
\hline 20 & July $18^{\text {th }} 2005$ & Q04 & Hybrid & $\mathrm{F}$ \\
\hline 21 & July $18^{\text {th }} 2005$ & Q15 & Hybrid & M \\
\hline
\end{tabular}


Table 2. Neotropical primates of genus Callithrix under captivity at Cetas/IBAMA, RJ

\begin{tabular}{|c|c|c|c|c|}
\hline № & Collect data & Cage & Specie & Sex \\
\hline 1 & Sept $13^{\text {th }} 2005$ & V01 & Hybrid & M \\
\hline 2 & Sept $13^{\text {th }} 2005$ & V01 & Hybrid & $\mathrm{F}$ \\
\hline 3 & Sept $13^{\text {th }} 2005$ & V01 & Hybrid & $\mathrm{F}$ \\
\hline 4 & Sept $13^{\text {th }} 2005$ & V03 & Hybrid & M \\
\hline 5 & Sept $13^{\text {th }} 2005$ & V03 & Hybrid & $\mathrm{F}$ \\
\hline 6 & Sept $13^{\text {th }} 2005$ & V03 & Hybrid & M \\
\hline 7 & Sept $13^{\text {th }} 2005$ & V04 & Hybrid & $\mathrm{F}$ \\
\hline 8 & Sept $13^{\text {th }} 2005$ & V04 & Hybrid & $\mathrm{F}$ \\
\hline 9 & Sept $13^{\text {th }} 2005$ & V05 & Hybrid & $\mathrm{F}$ \\
\hline 10 & Sept $13^{\text {th }} 2005$ & V05 & Hybrid & $\mathrm{F}$ \\
\hline 11 & Sept $13^{\text {th }} 2005$ & V05 & Hybrid & $\mathrm{F}$ \\
\hline 12 & Sept $13^{\text {th }} 2005$ & V05 & Hybrid & $\mathrm{F}$ \\
\hline 13 & Sept $13^{\text {th }} 2005$ & V06 & C. jacchus & M \\
\hline 15 & Sept $13^{\text {th }} 2005$ & V07 & Hybrid & $\mathrm{F}$ \\
\hline 16 & Sept $13^{\text {th }} 2005$ & V07 & Hybrid & M \\
\hline 17 & Sept $13^{\text {th }} 2005$ & V07 & Hybrid & $\mathrm{F}$ \\
\hline 18 & Sept $13^{\text {th }} 2005$ & V08 & Hybrid & $\mathrm{F}$ \\
\hline 19 & Sept $13^{\text {th }} 2005$ & V08 & Hybrid & $\mathrm{F}$ \\
\hline 20 & Sept $13^{\text {th }} 2005$ & V08 & Hybrid & M \\
\hline 21 & Sept $13^{\text {th }} 2005$ & V08 & Hybrid & $\mathrm{F}$ \\
\hline 22 & Sept $13^{\text {th }} 2005$ & E01 & Hybrid & M \\
\hline 24 & Sept $13^{\text {th }} 2005$ & E01 & C. jacchus & $\mathrm{F}$ \\
\hline
\end{tabular}

\section{RESULTS AND DISCUSSION}

From 21 Cebus, 16 showed anti-Toxoplasma gondii antibodies. Amongst the serum reactive primates, 12 were females and four were males (Table 3). They did not ingest raw meat since the arrival to Cetas/IBAMA, RJ; but it is not possible to discard the possibility of having been fed raw or partially cooked meat to these animals before arriving at the Center, as they came from uncertain origins. Cunningham et al. (1992) reported a toxoplasmosis outbreak among captive Squirrel monkey (Saimiri sciureus), with a $30 \%$ mortality and $100 \%$ morbidity rate; the cause of the

Table 3. Serological results in indirect hemagglutination test in Neotropical primates of genus Cebus

\begin{tabular}{cccccccccc}
\hline No & Sex & \multicolumn{7}{c}{ Hemagglutinant titles } \\
\cline { 3 - 9 } & & 16 & 32 & 64 & 128 & 256 & 512 & 1024 & 2048 \\
\hline 1 & $\mathrm{~F}$ & - & - & - & - & - & - & - & - \\
2 & $\mathrm{~F}$ & + & + & + & + & + & + & + & - \\
3 & $\mathrm{~F}$ & + & + & + & + & + & + & + & + \\
4 & $\mathrm{M}$ & + & + & + & + & + & + & + & + \\
5 & $\mathrm{~F}$ & + & + & + & + & + & + & + & + \\
6 & $\mathrm{~F}$ & + & + & + & + & + & + & + & + \\
7 & $\mathrm{M}$ & + & + & + & + & + & + & - & - \\
8 & $\mathrm{~F}$ & + & + & + & + & + & + & + & + \\
9 & $\mathrm{~F}$ & - & - & - & - & - & - & - & - \\
10 & $\mathrm{~F}$ & + & + & + & + & + & + & + & + \\
11 & $\mathrm{M}$ & + & + & + & + & + & + & + & + \\
12 & $\mathrm{~F}$ & - & - & - & - & - & - & - & - \\
13 & $\mathrm{~F}$ & + & + & + & + & + & + & + & + \\
14 & $\mathrm{M}$ & - & - & - & - & - & - & - & - \\
15 & $\mathrm{~F}$ & + & + & + & + & + & + & + & + \\
16 & $\mathrm{~F}$ & + & + & - & - & - & - & - & - \\
17 & $\mathrm{~F}$ & + & + & + & + & + & + & + & + \\
18 & $\mathrm{M}$ & - & - & - & - & - & - & - & - \\
19 & $\mathrm{~F}$ & + & + & + & + & + & + & + & - \\
20 & $\mathrm{~F}$ & + & - & - & - & - & - & - & - \\
21 & $\mathrm{M}$ & + & + & + & + & + & + & + & +
\end{tabular}

$\bar{a}$ Positive (+) and negative $(-)$ reactions in the indirect hemagglutination test. outbreak was identified as feeding small portions of raw equine meat

Analyzing Table 3, it can be seen that seropositivity in primates of the genus Cebus was very high, as $76.19 \%$ $(16 / 21)$ had anti-T. gondii antibodies in their sera. Results oppose current literature, with respect the great sensitivity of the New World primates to T. gondii (Remington et al. 1965, Anderson \& McClure 1982, Cunningham et al. 1992, Innes 1997, Epiphanio 2001). High titles of agglutinant anti-T. gondii antibodies in the serum samples of these animals leads to think that Capuchin monkeys had reacted to T. gondii infection neither coming to death nor acquiring clinically evidenced sequels. During the clinical evaluation at Cetas/IBAMA, the animals did not show any clinical signs related to the disease. There was no association between positivity to T. gondii and sex in the studied Capuchin monkeys ( $p>0.05$ ) using Fisher's exact test (Table 4).

In 22 Marmoset, only one animal had anti-T. gondii antibodies by indirect hemagglutination and the title was 32 (Table 5). Garcia et al. (2005) observed $30.2 \%$ positivity to anti-T. gondii antibodies in serum samples of free range Capuchin monkeys at the Paraná river basin. Titles were lower in comparison to the results of the present study. Although statistical data could be obtained and there is no information regarding origin of the studied Capuchin monkeys, it

Table 4. Association between serological reaction to Toxoplasma gondii and gender of genus Cebus primates

\begin{tabular}{lccc}
\hline \multicolumn{1}{c}{ Sex } & \multicolumn{2}{c}{ Indirect hemagglutination test } & \multirow{2}{*}{ Total } \\
\cline { 2 - 3 } & Positive & Negative & \\
\hline Male & 4 & 2 & 6 \\
Female & 12 & 3 & 15 \\
Total & 16 & 5 & 21
\end{tabular}

Fisher's exact test. $\mathrm{p}>0.05$.

Table 5. Serological results in indirect hemagglutination test in Neotropical primates of genus Callithrix

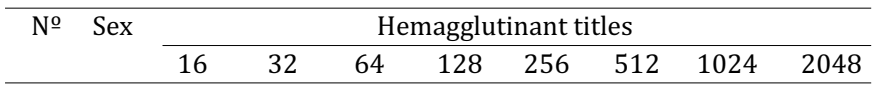

\begin{tabular}{llllllllll}
\hline 1 & M & - & - & - & - & - & - & - & - \\
2 & $\mathrm{~F}$ & + & + & - & - & - & - & - & - \\
3 & $\mathrm{~F}$ & - & - & - & - & - & - & - & - \\
4 & $\mathrm{M}$ & - & - & - & - & - & - & - & - \\
5 & $\mathrm{~F}$ & - & - & - & - & - & - & - & - \\
6 & $\mathrm{M}$ & - & - & - & - & - & - & - & - \\
7 & $\mathrm{~F}$ & - & - & - & - & - & - & - & - \\
8 & $\mathrm{~F}$ & - & - & - & - & - & - & - & - \\
9 & $\mathrm{~F}$ & - & - & - & - & - & - & - & - \\
10 & $\mathrm{~F}$ & - & - & - & - & - & - & - & - \\
11 & $\mathrm{~F}$ & - & - & - & - & - & - & - & - \\
12 & $\mathrm{~F}$ & - & - & - & - & - & - & - & - \\
13 & $\mathrm{M}$ & - & - & - & - & - & - & - & - \\
15 & $\mathrm{~F}$ & - & - & - & - & - & - & - & - \\
16 & $\mathrm{M}$ & - & - & - & - & - & - & - & - \\
17 & $\mathrm{~F}$ & - & - & - & - & - & - & - & - \\
18 & $\mathrm{~F}$ & - & - & - & - & - & - & - & - \\
19 & $\mathrm{~F}$ & - & - & - & - & - & - & - & - \\
20 & $\mathrm{M}$ & - & - & - & - & - & - & - & - \\
21 & $\mathrm{~F}$ & - & - & - & - & - & - & - & - \\
22 & $\mathrm{M}$ & - & - & - & - & - & - & - & - \\
24 & $\mathrm{~F}$ & - & - & - & - & - & - & - & -
\end{tabular}

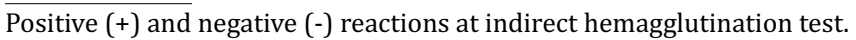


is possible that close relationship between these monkeys and humans was responsible to enhance T. gondii transmission. Contact with domestic cats and mainly the availability of raw or partially cooked meat for feeding could explain infection and higher hemagglutinant antibodies in serum samples of the animals studied.

Alouatta and Cebus species have respectively arboricole and terrestrials habits, and geophagy is reported as a source for mineral intake (Auricchio 1995). Geophagy would make infection possibly to occur in natural environments where definitive hosts can be find, e.g. Moorish cat (Herpailurus yagouaroundi), as explained by Garcia et al. (2005). However, such habit would not explain higher seroconvertion in captive animals. Species of the Callitrichidae family differed from the majority of Capuchin monkeys by having extremely arboricole biological habits in not-degraded areas. For this reason, these animals have less opportunity to get in contact with infective sources of T. gondii in natural environments.

Neotropical primates of the Callithrix genus had very low frequency of hemagglutinant antibodies in their sera. There were no previous reports on serologic studies in primates of this genus; however it is known that Callitrichidae species can be affected by acute and fatal toxoplasmosis (Epiphanio et al. 2003). Lower frequency of anti-T. gondii antibodies in Callithrix serum samples could be associated with the routine of toxoplasmosis cases in marmoset, beyond innumerable clinical case reports in these animals where unspecific symptoms were observed with an outcome of death. In this way, marmosets evaluated at the present study could be exactly those that had no contact with $T$. gondii. In this hypothesis, marmosets could be a New World primate family more susceptible to $T$. gondii infection.

Experimental studies on Neotropical primate species, with special regard to immunological tests with high speci- ficity in the detection of anti-T. gondii antibodies, as ELISA or "immunoblotting", lays on unavailability of commercial conjugates, becoming immunological studies in wild animals more difficult and rare.

\section{REFERENCES}

Anderson D.C. \& McClure H.M. 1982. Acute disseminated fatal toxoplasmosis in a squirrel monkey. J. Am. Vet. Med. Assoc. 181:1363-1366.

Auricchio P. 1995. Primatas do Brasil. Ed. Terra Brasilis, Arujá. 165p.

Cadavid A.P., Cañas L., Estrada J.J. \& Ramirez L.E. 1991. Prevalence of antiToxoplasma gondii antibodies in Cebus spp in the Santa Fe Zoological Park of Medellín, Colombia. J. Med. Primatol. 20:259-261.

Chhabra M.B., Mahajan R.C., Ganguly N.K. \& Chitkara N.L. 1976. Prevalence of Toxoplasma antibodies in rhesus monkeys in India. Trop. Geogr. Med. 28:101-103.

Cunningham A.A., Buxton D. \& Thompson K.M. 1992. An epidemic of toxoplasmosis in a captive colony of squirrel monkeys (Saimiri sciureus). J. Comp. Pathol. 107:207-219.

Ekanayake D.K., Rajapakse R.P., Dubey J.P. \& Dittus W.P. 2004. Seroprevalence of Toxoplasma gondii in wild toque macaques (Macaca sinica) at Polonnaruwa, Sri Lanka. J. Parasitol. 90:870-871.

Epiphanio S., Sá L.R., Teixeira R.H. \& Catão-Dias J.L. 2001. Toxoplasmosis in a wild-caught black lion tamarin (Leontopithecus chrysopygus). Vet. Rec. 149:627-628.

Epiphanio S., Sinhorini I.L. \& Catão-Dias J.L. 2003. Pathology of toxoplasmosis in captive new world primates. J. Comp. Pathol. 129:196-204.

Garcia J.L., Svoboda W.K., Chryssafidis A.L., Souza Malanski L. de, Shiozawa M.M., Moraes Aguiar L. de, Teixeira G.M., Ludwig G., Silva L.R. da, Hilst C. \& Navarro I.T. 2005. Sero-epidemiological survey for toxoplasmosis in wild New World monkeys (Cebus spp., Alouatta caraya) at the Paraná river basin, Paraná State, Brazil. Vet. Parasitol. 133:307-311.

Innes EA. 1997. Toxoplasmosis: comparative species susceptibility and host immune response. Comp. Immunol. Microbiol. Infect. Dis. 20:131138.

Remington J.S. Soave O.A. \& Davis J. 1965. A serological survey in three species of monkeys for antibodies to toxoplasma. Am. J. Trop. Med. Hyg. $14: 724-726$ 